Note

\section{Novel Acetamides Isolated from Scolecotrichum graminis Fuckel}

\author{
Hiroyasu TABUCHI, Akitoshi TAJIMI* \\ and Akitami ICHIHARA \\ Department of Agricultural Chemistry, Faculty of \\ Agriculture, Hokkaido University, \\ Sapporo 060, Japan \\ * Hokkaido National Agricultural Experiment Station, \\ Sapporo 061-01, Japan
}

Received June 6, 1991

In the course of our continuing research on phytotoxic compounds from Scolecotrichum graminis Fuckel, which causes a leaf streak disease of orchardgrass, we have reported the isolation of $(+)$-isocercosporin. ${ }^{1)}$ Here are described the isolation and structural elucidation by the synthesis of novel acetamide compounds $\mathbf{1}, \mathbf{2 a}$ and $\mathbf{2 b}$ from the same fungus, although these compounds have no significant activity. The isolation procedure for $\mathbf{1}, \mathbf{2 a}$ and $\mathbf{2 b}$ is described in the experimental section.

HR-EI-MS measurement of $1,[\alpha]_{\mathrm{D}}^{25}-69.8^{\circ}(c=1.0$, EtOH), showed a molecular ion at $m / z 143.0938$ (calcd. for $\left.\mathrm{C}_{7} \mathrm{H}_{13} \mathrm{NO}_{2}, 143.0946\right)$. The IR spectrum of 1 revealed absorption bands at $3300(\mathrm{NH}), 1720(\mathrm{CO})$ and 1650 (HNCO) $\mathrm{cm}^{-1}$. In the ${ }^{1} \mathrm{H}-\mathrm{NMR}$ spectrum of $\mathbf{1}$, a broad singlet at $\delta 6.45(1 \mathrm{H})$ replaceable with $\mathrm{D}_{2} \mathrm{O}$ was attributed to an amide proton. The signals of a triplet $(3 \mathrm{H})$ at $\delta 1.10$ and two double-quartets $(1 \mathrm{H}, 1 \mathrm{H})$ at $\delta 2.48$ and $\delta 2.60$ showed the presence of an ethyl group, which was attached to a carbonyl carbon. A singlet $(3 \mathrm{H})$ at $\delta 2.01$ was ascribed to acetyl protons. In spin decoupling experiment on the broad singlet $(1 \mathrm{H})$ at $\delta 6.45$, a methine quintet $(1 \mathrm{H})$ at $\delta$ 4.62 collapsed to a quartet $(J=7.1 \mathrm{~Hz})$, which indicates the presence of a $-\mathrm{COCH}(\mathrm{NHCO}-) \mathrm{CH}_{3}$ moiety. Thus, the structure of compound 1 was elucidated to be 2-acetamido3-pentanone.

The FD-MS of both $2 \mathrm{a},[\alpha]_{\mathrm{D}}^{22}-25.0^{\circ}(c=1.0, \mathrm{EtOH})$, and $2 \mathbf{b},[\alpha]_{\mathrm{D}}^{22}-188.0^{\circ}(c=0.5, \mathrm{EtOH})$, exhibited the $[\mathrm{MH}]^{+}$ion at $m / z 146$ and the $[2 \mathrm{M}+\mathrm{H}]^{+}$ion at $m / z 291$. The EI-HR-MS of $2 \mathrm{a}$ showed 127.0981 [ $\mathrm{M}^{+}-\mathrm{H}_{2} \mathrm{O}$; calcd. for $\left.\mathrm{C}_{7} \mathrm{H}_{13} \mathrm{NO}, 127.0996\right)$. The ${ }^{1} \mathrm{H}-\mathrm{NMR}$ spectra of both $\mathbf{2 a}$ and $\mathbf{2} \mathbf{b}$ were similar to that of $\mathbf{1}$, except for two methine multiplets $(1 \mathrm{H}, 1 \mathrm{H})$ at $\delta 3.56$ and $\delta 3.46$, respectively. These results indicate that $2 \mathrm{a}$ and $\mathbf{2 b}$ were diastereomers of 2-acetamido-3-pentanol, which was also obtained by reducing 1 with sodium borohydride in a ratio of $2: 1$.

In order to determine the absolute configurations, $1,2 a$ and $\mathbf{2 b}$ were synthesized via a Grignard reaction of 2$(N$-phthaloylamino)propanal (4) from L-alanine (Scheme 1). Aldehyde 4 , which was obtained by $N$-phthaloylation (phthalic anhydride, toluene, reflux, $3 \mathrm{hr}$ ), acid chloride formation (thionyl chloride, benzene, refiux, $12 \mathrm{hr}$ ) and Rosenmund reduction $\left(\mathrm{H}_{2}, 10 \% \mathrm{Pd} / \mathrm{C}\right.$, toluene, 100 $120^{\circ} \mathrm{C}, 2 \mathrm{hr}$ ) from L-alanine, ${ }^{2,3}$ was reacted with ethylmagnesium iodide in tetrahydrofuran at $-78^{\circ} \mathrm{C}$ for $2.5 \mathrm{hr}$ to give a mixture of $\mathbf{5 a}$ and $\mathbf{5 b}$ in a ratio of $81: 19$. Resulting alcohol 5a, which was separated from $\mathbf{5 b}$ by silica gel column chromatography, was treated with dihydropyran catalyzed by $p$-toluenesulfonic acid in dichloromethane $\left(0^{\circ} \mathrm{C} \rightarrow\right.$ room temperature, $\left.2 \mathrm{hr}\right)$ to give 6a. After removing the $N$-blocking group by hydrazine hydrate in ethanol (refiux, $1.5 \mathrm{hr}$ ), ${ }^{4}$ the resulting crude amine was treated with acetic anhydride in methanol (room temperature, $2 \mathrm{hr}$ ) to afford acetamide 7a. Removal of the THP group by p-toluenesulfonic acid in ethanol (room temperature, $2 \mathrm{hr}$ ) gave acetamide $\mathbf{2 a}$. By using the above-described procedures, $\mathbf{2} \mathbf{b}$ was synthesized from $\mathbf{5} \mathbf{b}$. Furthermore, synthetic $\mathbf{2 a}$ was converted to $\mathbf{1}$ by pyridinium dichromate.

The resulting synthetic $\mathbf{1}, \mathbf{2} \mathbf{a}$ and $\mathbf{2 b}$ exhibited chromatographic and spectral characteristics (MS, IR and ${ }^{1} \mathrm{H}-\mathrm{NMR}$ ) identical with natural $\mathbf{1}, \mathbf{2} \mathbf{a}$ and $\mathbf{2} \mathbf{b}$, respectively. Additionally, the observed optical rotation of synthetic $\mathbf{1}$, $[\alpha]_{\mathrm{D}}^{23}-60.0^{\circ}(c=1.0, \mathrm{EtOH}), 2 \mathrm{a},[\alpha]_{\mathrm{D}}^{22}-25.0^{\circ}(c=1.0$, $\mathrm{EtOH})$, and $2 \mathbf{b},[\alpha]_{\mathrm{D}}^{22}-170.0^{\circ}(c=0.4$, EtOH $)$, were in good agreement with the values for natural $\mathbf{1}, \mathbf{2 a}$ and $\mathbf{2 b}$. These comparisons establish that the absolute configurations of $\mathbf{1}, \mathbf{2 a}$ and $\mathbf{2 b}$ were all $2 S$. In order to establish the absolute configurations of the C-3 position of $\mathbf{2} \mathbf{a}$ and $\mathbf{2} \mathbf{b}$ according to Mosher's method, ${ }^{5.6)} 5$ a was converted to the $(S)$-MTPA ester of 5a (11) and the (R)-MTPA ester of 5a (12). In a solution, the carbinyl proton, ester carbonyl and triffuoromethyl groups of the MTPA moiety are oriented on the same plane. ${ }^{5)}$ Due to the diamagnetic effect of the benzene ring, $\mathrm{H}_{4}$ and $\mathrm{H}_{5}$ of the (R)-MTPA ester of $5 \mathbf{a}(\mathbf{1 2})$ showed ${ }^{1} \mathrm{H}-\mathrm{NMR}$ signals upfield relative to those of the $(S)$-MTPA ester of $\mathbf{5 b}(\mathbf{1 1})$. On the other hand, $\mathrm{H}_{1}$ and $\mathrm{H}_{2}$ of $\mathbf{1 2}$ showed signals downfield of those of $\mathbf{1 1}$ (Scheme 1). These results indicate that the absolute configuration of the C-3 position of $5 \mathbf{a}$ was $R$, and that those of $\mathbf{2 a}$ and $2 \mathbf{b}$ were $R$ and $S$, respectively.

Although 1, $\mathbf{2 a}$ and $\mathbf{2 b}$ showed no significant inhibitory activity toward the growth of lettuce seeds even at a high concentration of $500 \mathrm{ppm}$, these compounds are interesting from the standpoint of biosynthesis, which would involve transformation from L-alanine.

\section{Experimental}

The analytical instruments used were as follows: FD-MS, JEOL 01SG-2; EI-MS, JEOL DX-300; IR spectra, Hitachi Model $285 ;{ }^{1} \mathrm{H}-\mathrm{NMR}$ spectra, Bruker AM-500 $(500 \mathrm{MHz}$ with $\mathrm{CDCl}_{3}$ as the solvent); optical rotation, JASCO DIP-4.

Isolation and purification. Scolecotrichum graminis 
<smiles>C[C@H](N)C(=O)O</smiles>

L-alanine (3)<smiles>CCCCCCCCC=O</smiles>

$\stackrel{4}{\sim}$

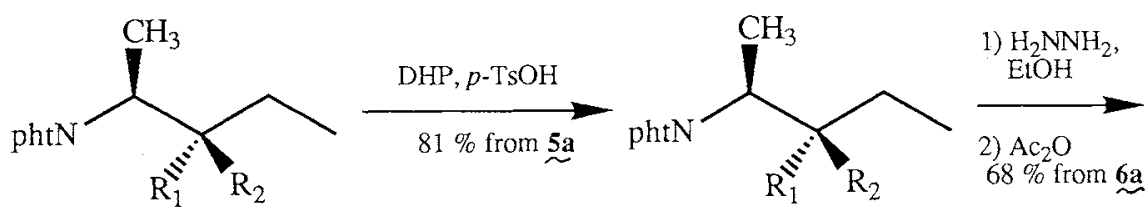

$5 \mathrm{a}(3 R): 5 \mathrm{~b}(3 S)=81: 19$ $\left\{\begin{array}{l}\mathrm{R}_{1}=\mathrm{H} \\ \mathrm{R}_{2}=\mathrm{OH}\end{array}\left\{\begin{array}{l}\mathrm{R}_{1}=\mathrm{OH} \\ \mathrm{R}_{2}=\mathrm{H}\end{array}\right.\right.$ 6a $(3 R) ; \mathrm{R}_{1}=\mathrm{H}, \mathrm{R}_{2}=$ OTHP $6 \mathrm{~b}(3 S) ; \mathrm{R}_{1}=\mathrm{OTHP}, \mathrm{R}_{2}=\mathrm{H}$<smiles>[R4][C@H](C)C([R2])([R4])CC</smiles>

$7 \mathrm{a}(3 R) ; \mathrm{R}_{1}=\mathrm{H}, \mathrm{R}_{2}=$ OTHP $\mathrm{Tb}(3 S) ; \mathrm{R}_{1}=\mathrm{OTHP}, \mathrm{R}_{2}=\mathrm{H}$

\section{$p$ - $\mathrm{TsOH}, \mathrm{EtOH}$}

$85 \%$ from $7 \mathrm{a}$

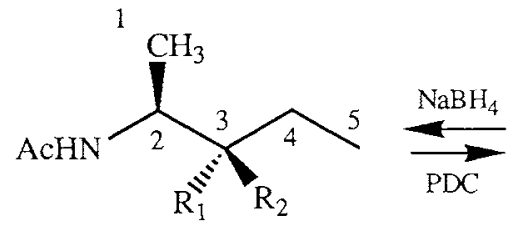

$2 \mathrm{a}(3 R) ; \mathrm{R}_{1}=\mathrm{H}, \mathrm{R}_{2}=\mathrm{OH}$ $\underset{2 b}{2}(3 S) ; \mathrm{R}_{1}=\mathrm{OH}, \mathrm{R}_{2}=\mathrm{H}$<smiles>CCN[C@@H](C)C(=O)CC</smiles>

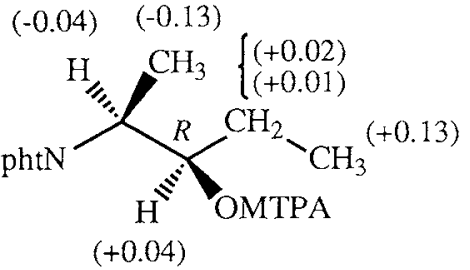

MTPA ester of $5 \mathbf{a}^{*}$

Scheme 1.

* $\Delta \delta=\delta_{S}-\delta_{R}$. The numerical value denoting each proton is the chemical shift difference obtained by subtracting the chemical shift $\left(\delta_{R}\right)$ of a proton of the $(R)$-MTPA ester $(12)$ from that $\left(\delta_{S}\right)$ of the $(S)$-MTPA ester (11) [ $\Delta \delta$ values are given in ppm $\left.\left(\mathrm{CDCl}_{3}, 500 \mathrm{MHz}\right)\right]$.

Fuckel supplied by Hokkaido National Agricultural Experiment Station, Sapporo, Japan, was seeded into $500-\mathrm{ml}$ Erlenmeyer flasks containing $150 \mathrm{ml}$ of a potato extract medium. After the fungus (143 flasks) had been incubated at $25^{\circ} \mathrm{C}$ for 30 days in a surface culture, the culture filtrates ( 20 liters) were concentrated in vacuo to give a concentrate ( 1 liter), which was extracted with ethyl acetate. The extracts were dried over $\mathrm{Na}_{2} \mathrm{SO}_{4}$ and con- 
centrated to dryness, and the residue was fractionated by silica gel column chromatography with $\mathrm{CHCl}_{3}-\mathrm{MeOH}$ $(9: 1)$ as the eluent into eight fractions (Fr. 1-8). Fr. 1 and Fr. 2, which showed a spot of $R_{f}=0.36$ and two spots of $R_{f}=0.26$ and 0.20 on silica gel TLC with ethyl acetate by the Rydon-Smith reagent, respectively, were subjected to silica gel preparative TLC with ethyl acetate to give 1 (14.5 mg), $\mathbf{2 a}$ (11.0 $\mathrm{mg}$ ) and $\mathbf{2 b}$ (9.0 $\mathrm{mg})$.

(2S)-2-acetamido-3-pentanone (1). $[\alpha]_{\mathrm{D}}^{25}-69.8^{\circ}(c=1.0$, EtOH). EI-MS $m / z(\%): 143[\mathrm{M}]^{+}(0.12), 69(100)$. EI-HR-MS $m / z: 143.0938\left(\mathrm{M}^{+}\right.$; calcd. for $\mathrm{C}_{7} \mathrm{H}_{13} \mathrm{NO}_{2}$, 143.0946). IR $v_{\max }$ (film) $\mathrm{cm}^{-1}: 3300,1720,1650 .{ }^{1} \mathrm{H}-\mathrm{NMR}$ : $\delta 6.45(1 \mathrm{H}$, br. s, NH), 4.62 (1H, quintet, $J=7.1 \mathrm{~Hz}, 2-\mathrm{H}$ ), $2.60(1 \mathrm{H}, \mathrm{dq}, J=18.0,7.3 \mathrm{~Hz}, 4-\mathrm{H}), 2.48(1 \mathrm{H}, \mathrm{dq}, J=18.0$, $7.3 \mathrm{~Hz}, 4-\mathrm{H}), 2.01\left(3 \mathrm{H}, \mathrm{s}, \mathrm{CH}_{3} \mathrm{CO}-\right), 1.35(3 \mathrm{H}, \mathrm{d}, J=7.1 \mathrm{~Hz}$, $1-\mathrm{H}), 1.10(3 \mathrm{H}, \mathrm{t}, J=7.2 \mathrm{~Hz}, 5-\mathrm{H})$.

(2S,3R)-2-acetamido-3-pentanol (2a). $[\alpha]_{\mathrm{D}}^{22}-25.0^{\circ}$ $(c=1.0, \mathrm{EtOH})$. EI-MS $m / z(\%): 127\left[\mathrm{M}-\mathrm{H}_{2} \mathrm{O}\right]^{+}(2.85)$, 69 (100). EI-HR-MS $m / z$ : $127.0981\left(\mathrm{M}^{+}-\mathrm{H}_{2} \mathrm{O}\right.$; calcd. for $\left.\mathrm{C}_{7} \mathrm{H}_{13} \mathrm{NO}, 127.0996\right)$. IR $v_{\max }($ film $) \mathrm{cm}^{-1}: 3350,1640$. ${ }^{1} \mathrm{H}-\mathrm{NMR}: \delta 5.68(1 \mathrm{H}$, br. s, NH), $4.01(1 \mathrm{H}, \mathrm{m}, 2-\mathrm{H}), 3.56$ $(1 \mathrm{H}, \mathrm{m}, 3-\mathrm{H}), 1.99\left(3 \mathrm{H}, \mathrm{s}, \mathrm{CH}_{3} \mathrm{CO}-\right), 1.40-1.60(2 \mathrm{H}, \mathrm{m}$, 4-H), 1.25 (1H, br.s, $3-\mathrm{OH}), 1.10(3 \mathrm{H}, \mathrm{d}, J=6.9 \mathrm{~Hz}, 1-\mathrm{H})$, $0.99(3 \mathrm{H}, \mathrm{t}, J=7.4 \mathrm{~Hz}, 5-\mathrm{H})$.
(2S,3S)-2-acetamido-3-pentanol $(\mathbf{2 b}) . \quad[\alpha]_{\mathrm{D}}^{22}-188.0^{\circ}$ $\left(c=0.5\right.$, EtOH). FD-MS $m / z(\%): 291[2 \mathrm{M}+\mathrm{H}]^{+}(16.40)$, $146[\mathrm{MH}]^{+}(100)$. IR $\gamma_{\max }($ film $) \mathrm{cm}^{-1}: 3300,1630$. ${ }^{1} \mathrm{H}-\mathrm{NMR}: \delta 5.68(1 \mathrm{H}$, br. s, NH), $4.01(1 \mathrm{H}, \mathrm{m}, 2-\mathrm{H}), 3.46$ $(1 \mathrm{H}, \mathrm{m}, 3-\mathrm{H}), 2.00\left(3 \mathrm{H}, \mathrm{s}, \mathrm{CH}_{3} \mathrm{CO}-\right), 1.40-1.60(2 \mathrm{H}, \mathrm{m}$, $4-\mathrm{H}), 1.25(1 \mathrm{H}$, br.s, $3-\mathrm{OH}), 1.20(3 \mathrm{H}, \mathrm{d}, J=6.8 \mathrm{~Hz}, 1-\mathrm{H})$, $0.96(3 \mathrm{H}, \mathrm{t}, J=7.5 \mathrm{~Hz}, 5-\mathrm{H})$.

Acknowledgments. We are grateful to Mr. Kenji Watanabe and Mrs Eri Fukushi (both of Hokkaido Univ.) for measuring mass spectra.

\section{References}

1) H. Tabuchi, A. Tajimi and A. Ichihara, Agric. Biol. Chem., 55, 2675 (1991).

2) H. Newman, J. Am. Chem. Soc., 95, 4098 (1973).

3) Y. Moriyama, Y. Saitoh, Y. Igarashi, T. Sugimoto, T. Takahashi and H. Khuong, Koen Yoshishu-Tennen Yuki Kagobutsu Toronkai, 22nd, 532 (1979).

4) H. Newman, J. Org. Chem., 39, 100 (1974).

5) J. A. Dale and H. S. Mosher, J. Am. Chem. Soc., 95, 512 (1973).

6) I. Ohtani, T. Kusumi, M. O. Ishitsuka and $\mathrm{H}$. Kakisawa, Tetrahedron Lett., 30, 3147 (1989). 